\title{
EFFECTS OF in-situ BIOCONVERSION OF FARM RESIDUES ON GROWTH AND QUALITY OF BANANA $c v$. Nendran IN LATERITE SOILS OF KERALA
}

\author{
Mayade vi $\mathrm{MR}^{* 1}$, Sushama $\mathrm{PK}^{1}$, Sandeep $\mathrm{S}^{2}$ \\ ${ }^{1}$ Department of Soil Science and Agricultural Chemistry, College of Horticulture, Kerala Agricultural University, Thrissur - 680656, Kerala, India \\ ${ }^{2}$ Department of Soil Science, Kerala Forest Research Institute, Peechi, Thrissur - 680653, Kerala, India
}

Received - March 04, 2017; Revision - April 12, 2017; Accept ed - June 01, 2017

Avail able Online - June 30, 2017

DOI: http://dx.doi.org/10.18006/2017.5(3).341.350

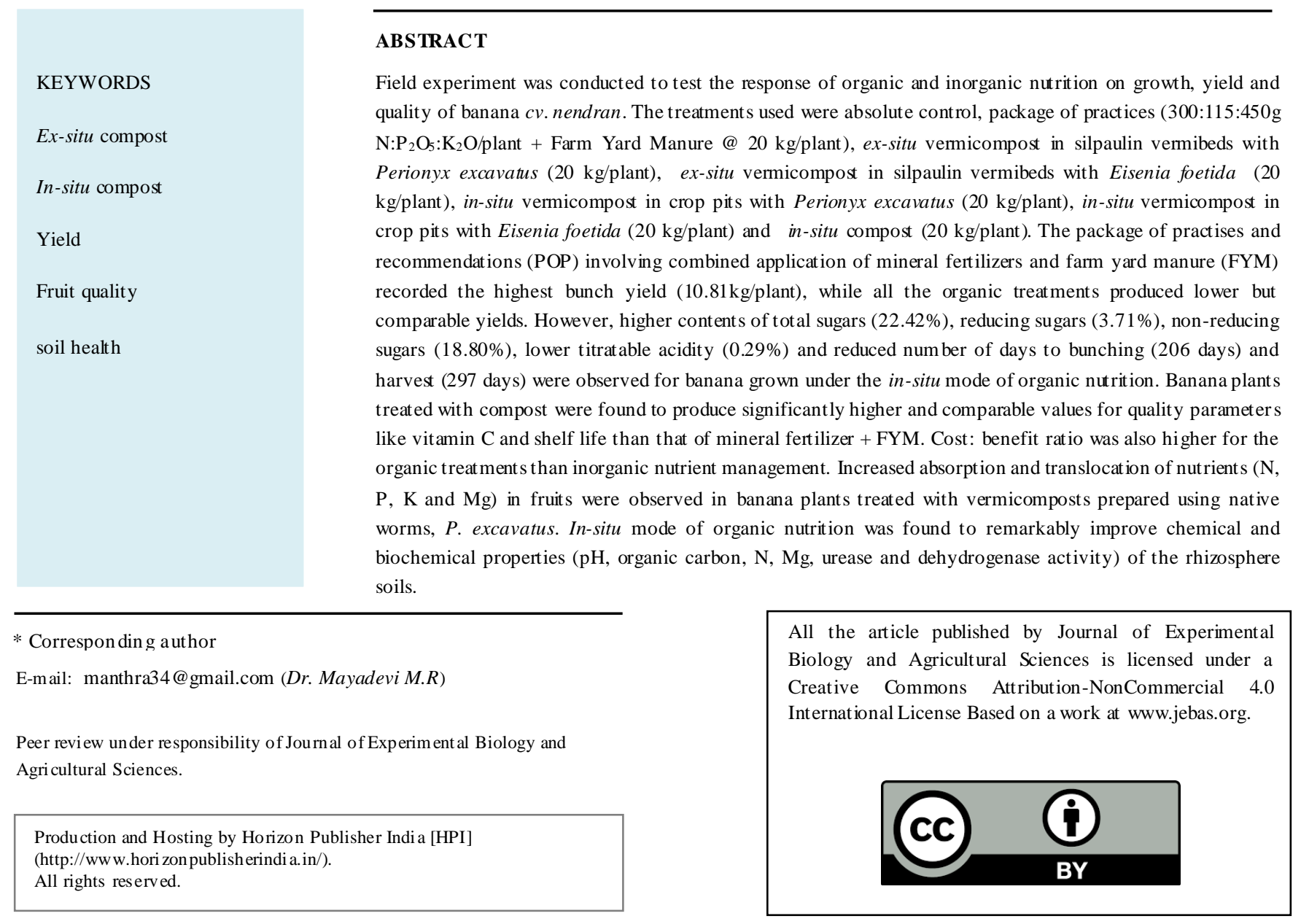




\section{Introduction}

Banana and plantains occupy the fourth important position among universal food commodities. It was grown in about 120 countries in the world with a production of 86 metric ton (National Horticultural Board, 2015). In India, it is cultivated in 4.6 lakh ha area (13\% of total fruit area) with a production of 14.2 metric ton (33.4\% to the total fruit production) and a productivity of $30.5 \mathrm{mt}$ / ha. In Kerala, banana is a major fruit crop raised on plantation scale and spans an area of 61936 ha. Current production of banana is 545431t and productivity is $14.1 \mathrm{mt} / \mathrm{ha}$ in Kerala (Government of Kerala, 2016). Nendran is the most popular cultivar of banana in the state of Kerala due to its market and commercial inclinations and occupies 50 percent share of total banana export from the state (National Horticulture Mission, 2005).

However the production of horticultural crops like banana faces many threats such as low productivity, inferior quality, high capital cost of cultivation, high incidence of pests and diseases (Balamohan \& Kavitha, 2005). Moreover banana generates about $220 \mathrm{t}$ of crop residues / ha in the form of fibrous pseudostem, leaves, peduncle and rhizomes after harvest of the bunch (Ingale et al., 2014). These biomass was absolutely treated as waste in most of the states of India and farmers incur about ₹ 8000 to ₹ 10000 / ha for disposing pseudostem alone (Indian Agricultural Research Institute, 2012). Disposal of pseudostem in regular ways like field bunds and natural drains, harbours insect pests and pathogens and acts as breeding sites for stray dogs, rodents etc. The pathogens were transmuted and much dreadful diseases like dengue fever, malaria and plague are spreading day by day. This situation is going to be worsened in the ensuing years, with accelerated urbanization and scarcity of land areas. Moreover the increased usage of pesticides, high analysis fertilizers and plant protection chemicals add to the irreversible degradation of the air, water and soil. Indiscriminate stubble burning expels more $\mathrm{CO}_{2}$ to the atmosphere as evidenced by the recent Delhi smog pollution (www. indianexpress.com). Proper management of banana residue poses a challenge to the farmers and at the same time offers great scope for recycling and use in subsequent crop. The escalating costs of chemical fertilizers and its undesirable effects on soil properties have led to inclusion of organic manures in cultivation of crops. Incorporation of crop residues into soil or converting them into composts is an easy way of waste disposal and managing the organic matter requirement of soils (Indian Agricultural Research Institute, 2012).

Composting is essentially a microbial alteration of mixed organic substrates, under controlled conditions into hygienic, humus rich, relatively stable product which can be used to improve soil physical conditions and nourish crop plants. According to Aremu et al. (2012) the improved growth of plants due to composting may be attributed to the humic acids present in the composts which influence lateral root proliferation, stimulate nutrient uptake and thereby plant development (Trevisan et al., 2010).
Vermicomposting on the other hand, is a mesophilic oxidative conversion of organic matter to mucus coated granular worm casts through the combined action of microorganisms and earthworms. Vermicomposting, besides being a good nutrient source also has an additional advantage of biogenic calcium carbonate enrichment which neutralizes soil acidity (Juarez et al., 2011), hence got the advantage as a soil conditioner in the acid soils of Kerala. Most of the work on earthworms in India is confined to vermicomposting using exotic earthworm species and very little information is available on the indigenous fauna of worms with respect to their utility in vermicomposting or in improving soil health.

Ex-situ composting methods employ the preparation of composts outside the field in suitable containers and in states like Kerala, where wages and labour charges are high, this adds to cost of cultivation. In-situ composting emphasises the production of composts from the residues generated from the field which effectively utilize farm wastes in the field itself and thereby cut down the waste management costs drastically and improve soil health at the planting sites (Masciandaro et al., 2000; Athani \& Hulamani, 2000; Sarma et al, 2012). Masciandaro et al. (2000) exhorted the addition of fresh sludge directly to soil for in-situ composting using Eisenia foetida. Exotic earthworm species like Eisenia foetida, Eudrillus eugeniae and native species like Perionyx excavatus were commercially exploited for organic waste reprocessing under controlled environment (Pattnaik \& Reddy, 2010). But their potential in in-situ waste management in the soil environment wherein the climate and ecology are highly variable is not much investigated. Hence exploring the effect of these in-situ developed vermicomposts (using both exotic and native earthworms) vis-a-vis crop and soil health will help to further the cause of such methodologies in organic banana cultivation.

\section{Materials and Me thods}

\subsection{Experiment de tails}

Field experiment was conducted to assess the growth, yield and crop quality of banana var. nendran by using composts prepared using ex-situ and in-situ modes against recommended doses of fertilizers at Banana Research Station, Kannara, Kerala. The treatment combinations included absolute control (soil) and recommended package of practises (POP) i.e.300: 115: $450 \mathrm{~g} \mathrm{~N}$ : $\mathrm{P}_{2} \mathrm{O}_{5}: \mathrm{K}_{2} \mathrm{O} /$ plant $+\mathrm{FYM}$ at the rate of $20 \mathrm{~kg} /$ plant (Kerala Agricultural University, 2011). The organic treatments included basal application of ex-situ and in-situ vermicomposts prepared using native and exotic earthworm species at the rate of $20 \mathrm{~kg} /$ plant. For vermicomposting native Perionyx excavatus and exotic Eisenia foetida were used. The ex-situ vermicomposts were prepared in silpaulin vermibeds using E. foetida (Ex-E) and $P$. excavatus (Ex-P) and were applied at the rate of $20 \mathrm{~kg}$ per pit. Exsitu vermicomposts were applied to the pits one week before planting. All the pits were covered with soil and left as such for one week. 
In-situ vermicomposts using $P$. excavatus (In-P) and E. foetida (InE) were prepared in banana planting pits itself (size $50 \mathrm{~cm} \times 50 \mathrm{~cm}$ x $50 \mathrm{~cm}$ ) three months prior to planting along with control without earthworms (In-C).

Three months old tissue culture banana $c v$. nendran plants were used as test crop. For each replication, four plants were selected (total of 12 plants per treatment). Banana plants grown under POP, were given fertilizers $\mathrm{N}: \mathrm{P}_{2} \mathrm{O}_{5}: \mathrm{K}_{2} \mathrm{O}$ at the rate of 300: 115: $450 \mathrm{~g} /$ plant in six split doses through urea, rajphos and muriate of potash respectively. Experimental soils were collected and analysed for organic carbon using Wet digestion (Walkley \& Black, 1934) available N (Subbiah \& Asija, 1956) and available Ca and Mg by neutral normal ammonium acetate extraction (Jackson, 1958). Experimental soils were low in organic carbon $(0.59 \%)$, available $\mathrm{N}(264.03 \mathrm{~kg} / \mathrm{ha})$ and available $\mathrm{Mg}(83.39 \mathrm{mg} / \mathrm{kg})$. All the biometric observations were taken at the time of bunching. The yield attributes were recorded at harvesting of bunches. The fruit samples were taken from the D finger and were kept for ripening.

\subsection{Physico-chemical characterization of compost, soil and plant}

The composts prepared were subject to chemical analysis: $\mathrm{pH}, \mathrm{N}$, $\mathrm{P}, \mathrm{K}$ and $\mathrm{Ca}$ was estimated by using the standard procedures as outlined in Fertilizer Control Order, (Government of India, 1985). The auxin like activity of humic substances in composts was hypothesised by many authors (Trevisan et al., 2010; Smith, 2012; Canellas \& Olivares, 2014). Indole Acetic Acid is a premier bioregulator regulates the growth of meristematc tissues. The concentrations of auxins in plants are regulated by the activity of the IAA oxidase enzyme. In soils, auxin production is purely biogenic and mainly by the action of microbes on L-tryptophan added through root exudates (Dakora \& Phillips, 2002) which works as physiological precursor for the biosynthesis of auxin in plants and microorganisms. Hence the indole acetic acid content in composts was determined and expressed as amount of un-oxidized auxin or activity of indole acetic acid oxidase enzyme using Salk woski reagent $\left(2 \mathrm{ml} 0.5 \mathrm{M} \mathrm{FeCl}_{3}\right.$ and $\left.98 \mathrm{ml} 35 \% \mathrm{HClO}_{4}\right)$ and pink colour intensity was measured using spectrophotometer at 535nm (Wohler, 1997). Dehydrogenase activity was assessed according to Pepper et al. (2004). The intensity of red colour due to formation of 1,3, 5 triphenylformazan (TPF) was determined spectrophotometrically at $485 \mathrm{~nm}$ and results were expressed as $\mathrm{mg}$ TPF $\mathrm{kg}^{-1}$ day $^{-1}$ compost. The total viable microbial cells were determined by serial dilution plate technique (Wollum, 1982). The humic acids were estimated using sequential fractionation procedure of Schintzer (1982).

Represent ative soil samples were collected from rhizosphere (0-30 $\mathrm{cm}$ depth) and analysed as per standard procedures as outlined by Jackson (1958).

Analyses of plant samples for $\mathrm{C}, \mathrm{N}$, and $\mathrm{S}$ were carried out using CHNS analyser (Model: Elementar Vario EL Cube). Powdered substrates were sieved ( $2 \mathrm{~mm}$ sieve) and sub samples $(0.5 \mathrm{~g})$ were digested with concentrated $\mathrm{HNO}_{3}$ in a microwave digestion system (Model: MARSX 250/40). Nutrient estimation was done in the acid extract using inductively coupled argon plasma optical emission spectrometer (ICP- OES Model: Optima 8x00). The fruit quality parameters were assessed using the protocols as prescribed by Association of Official Analytical Chemists (2000).

\subsection{Statistical analysis}

Analysis of variance (ANOVA) was done using SPSS (Version 20) to test the level of significance between treatments means (Das \& Giri, 1986).

\section{Results and Discussions}

\subsection{Chemical and biochemical characters of compost}

The $\mathrm{pH}$ of resultant composts ranged from neutral to moderately alkaline (7.1 to 8.3). Ex-situ composts have significantly higher $\mathrm{pH}$ than those prepared under in-situ mode of composting. The $\mathrm{pH}$ of the experimental soil was under strongly acidic range (4.7). However, in-situ mode of composting was found to have a significant ameliorating effect on the soil $\mathrm{pH}$ of the crop pits (Table 1).

The sum total of $\mathrm{N}, \mathrm{P}_{2} \mathrm{O}_{5}$ and $\mathrm{K}_{2} \mathrm{O}$ produced by compost and vermicomposts, irrespective of the treatments were above 2.5 percent, hence can be considered of good quality as prescribed by the fertilizer (Control) Order (Government of India, 1985). The enhanced levels of primary nutrients in the compost and vermicompost as compared to initial substrates indicated efficient decomposition of residues by the combined action of earthworms and microbes. Studies have revealed that organic residue decomposition by earthworms and microbes accelerates nitrogen mineralization process and thereby the substrate nitrogen profile (Suthar, 2009; Parthasarathi, 2010; Parthasarathi et al., 2016). In earthworms, $60-70 \%$ (dry mass) of the body tissue is made up of proteins and a major portion of this is mineralized from the dead tissues of worms and returned to the soil during composting. The content of $\mathrm{P}$ in the resultant composts was also higher than the initial substrate concentration. This enrichment of $\mathrm{P}$ occurs due to the phosphatase enzyme mediated conversion of $\mathrm{P}$ to available forms in the earthworm gut (Lee, 1992; Vinotha et al., 2000). Recently Parthasarathi (2010) have been also reported 6-8 folds increase in available phosphorus cont ent in vermicasts produced by E. eugeniae, E. fetida, L. mauritii and P. excavatus. Potassium contents in the composts and vermicomposts was also higher than the initial material and this was in agreement with previous reports that the composting process accelerates microbial populations in the residues and subsequently enriches them with more available plant nutrients (Suthar, 2009; Parthasarathi et al., 2007; Parthasarathi, 2010).

In crop pits (in-situ) E. foetida was found best for enriching Ca contents in composts. Padmavathiamma et al. (2008) suggested that this $\mathrm{Ca}$ enrichment occurs in vermicasts when soil and 
Table 1 Chemical and biochemical characteristics of composts used for the experiment

\begin{tabular}{|c|c|c|c|c|c|c|c|c|}
\hline \multirow[b]{2}{*}{ Treatments } & \multicolumn{3}{|c|}{ Chemical characteristics } & \multicolumn{5}{|c|}{ Biochemical characteristics } \\
\hline & $\mathrm{pH}$ & $\begin{array}{c}\mathrm{N}+\mathrm{P}_{2} \mathrm{O}_{5}+\mathrm{K}_{2} \mathrm{O} \\
(\%)\end{array}$ & $\begin{array}{c}\mathrm{Ca} \\
\text { as } \mathrm{CaO}(\%)\end{array}$ & $\begin{array}{l}\text { Compost } \\
\text { yield }(\%)\end{array}$ & $\begin{array}{c}\text { Auxin } \\
\text { equivalents } \\
\text { ( } \mu \mathrm{g} \mathrm{g}^{-1} \text { of } \\
\text { compost) }\end{array}$ & $\begin{array}{c}\text { Dehydrogenase } \\
\text { activity } \\
\left(\left(\text { mg TPF day }{ }^{-1} \mathrm{~kg}^{-1} \text { of }\right.\right. \\
\text { compost })\end{array}$ & $\begin{array}{c}\text { Viable } \\
\text { microbial } \\
\text { count } \\
\left(10^{4} \mathrm{cfu} \mathrm{g}^{-1}\right)\end{array}$ & $\begin{array}{l}\text { Humic Acid } \\
\text { content (\%) }\end{array}$ \\
\hline S & $\begin{array}{c}4.64 \\
(0.12)\end{array}$ & $\begin{array}{c}0.73 \\
(0.02)\end{array}$ & $\begin{array}{c}0.10 \\
(0.00)\end{array}$ & - & $\begin{array}{c}2.13 \\
(0.80)\end{array}$ & $\begin{array}{c}7.89 \\
(1.03)\end{array}$ & $\begin{array}{c}363.42 \\
(2.26)\end{array}$ & $\begin{array}{c}7.46 \\
(0.33)\end{array}$ \\
\hline Ex-C & $\begin{array}{c}7.95 \\
(0.12)\end{array}$ & $\begin{array}{c}4.47 \\
(0.44)\end{array}$ & $\begin{array}{c}0.56 \\
(0.05)\end{array}$ & $\begin{array}{l}70.83 \\
(6.64)\end{array}$ & $\begin{array}{c}9.86 \\
(0.35)\end{array}$ & $\begin{array}{l}64.43 \\
(3.45)\end{array}$ & $\begin{array}{l}723.34 \\
(17.39)\end{array}$ & $\begin{array}{l}28.61 \\
(7.28)\end{array}$ \\
\hline Ex-P & $\begin{array}{c}8.27 \\
(0.11)\end{array}$ & $\begin{array}{c}4.67 \\
(0.16)\end{array}$ & $\begin{array}{c}0.53 \\
(0.02)\end{array}$ & $\begin{array}{l}60.41 \\
(5.98)\end{array}$ & $\begin{array}{l}18.69 \\
(2.43)\end{array}$ & $\begin{array}{l}1798.63 \\
(120.69)\end{array}$ & $\begin{array}{l}480.38 \\
(17.22)\end{array}$ & $\begin{array}{l}24.99 \\
(1.16)\end{array}$ \\
\hline Ex-E & $\begin{array}{c}8.22 \\
(0.13)\end{array}$ & $\begin{array}{c}4.82 \\
(0.33)\end{array}$ & $\begin{array}{c}0.55 \\
(0.08)\end{array}$ & $\begin{array}{l}62.50 \\
(4.98)\end{array}$ & $\begin{array}{l}26.02 \\
(0.87)\end{array}$ & $\begin{array}{c}1394.86 \\
(31.80)\end{array}$ & $\begin{array}{l}445.34 \\
(5.99)\end{array}$ & $\begin{array}{l}32.79 \\
(5.36)\end{array}$ \\
\hline In-P & $\begin{array}{c}7.05 \\
(0.05)\end{array}$ & $\begin{array}{c}1.93 \\
(0.19)\end{array}$ & $\begin{array}{c}0.36 \\
(0.16)\end{array}$ & $\begin{array}{l}69.00 \\
(3.77)\end{array}$ & $\begin{array}{c}6.05 \\
(0.77)\end{array}$ & $\begin{array}{l}249.89 \\
(10.28)\end{array}$ & $\begin{array}{l}455.14 \\
(8.40)\end{array}$ & $\begin{array}{l}17.71 \\
(0.64)\end{array}$ \\
\hline In-E & $\begin{array}{c}7.19 \\
(0.24)\end{array}$ & $\begin{array}{c}2.64 \\
(0.21)\end{array}$ & $\begin{array}{c}0.69 \\
(0.04)\end{array}$ & $\begin{array}{l}62.00 \\
(4.14)\end{array}$ & $\begin{array}{c}7.75 \\
(0.65)\end{array}$ & $\begin{array}{l}423.56 \\
(76.22)\end{array}$ & $\begin{array}{l}652.05 \\
(11.46)\end{array}$ & $\begin{array}{l}25.99 \\
(3.68)\end{array}$ \\
\hline In-C & $\begin{array}{c}7.29 \\
(0.06)\end{array}$ & $\begin{array}{c}2.24 \\
(0.21)\end{array}$ & 0.46 & $\begin{array}{l}70.67 \\
(2.18)\end{array}$ & $\begin{array}{c}4.91 \\
(0.20)\end{array}$ & $\begin{array}{l}218.53 \\
(86.55)\end{array}$ & $\begin{array}{l}463.08 \\
(57.39)\end{array}$ & $\begin{array}{l}42.15 \\
(7.70)\end{array}$ \\
\hline $\mathrm{CD}$ at $5 \%$ & 0.43 & 0.77 & 0.25 & - & 3.28 & 93.83 & 72.08 & 7.46 \\
\hline
\end{tabular}

*Values in parentheses indicate standard error of means; S:Absolute control; Ex-C: ex-situ compost in silpaulin vermibeds (20 kg / plant) ; Ex-P: ex-situ vermicompost in silpaulin vermibeds with Perionyx excavatus $(20 \mathrm{~kg} / \mathrm{plant})$; Ex-E: ex-situ vermicompost in silpaulin vermibeds with E. foetida $(20 \mathrm{~kg} /$ plant); In-P: in-situ vermicompost in crop pits with P. excavatus (20 kg / plant); In-E: in-situ vermicompost in crop pits with $E$. foetida (20 kg / plant) and In-C: in-situ compost in crop pits $(20 \mathrm{~kg} /$ plant $)$

substrates pass through the digestive tract of earthworms. The results of the present study also confirmed this and all the vermicomposting treatments had significantly higher $\mathrm{Ca}$ contents than control. Vermicompost produced in the silpaulin vermibeds showed significantly higher compost yield, total primary nutrient content and auxin content than those produced in banana planting pits.

The relatively low amount of nutrients in composts prepared insitu can be attributed to high leaching, fixation or absorption by nearby small plants. The higher microbial population under $e x$-situ composting process would have led to an increase in compost yield (\% w/w basis). On the other hand, the high compost yield under In$\mathrm{P}$ can be attributed to the higher net individual and total biomass gain by indigenous $P$. excavatus. However, under ex-situ mode of composting in silpaulin vermibeds, the conditions were more or less uniform and loss of water was limited and hence with high moisture stagnation, P. excavatus failed to produce the desirable growth and multiplication.

Though the dehydrogenase activity is the index of microbial activity and was higher in Ex-P, it was found to have no correlation with the total microbial count of the treatment. The mismatch between enzyme activity and total microbial count was also reported by Luo et al. (2001) as the carbon expenditure for enzyme induced microbial respiration could not contribute to the growth and proliferation of microbes. Each type of respiratory carbon expenditure may differ in its response to soil organic matter quality and availability and this differentiation can impact the dynamics of the microbial growth independent of enzyme concentration (Allison et al., 2010).

\subsection{Growth and yield attributes of banana $c v$. Nendran}

The study revealed that the modes of nutrition had significant influence on the yield of banana and was observed in the bunch and growth characteristics like number of hands per bunch, number of fingers per hand, weight of fingers and number of functional leaves. There was significant positive correlation of yield with weight of finger $\left(\mathrm{r}=0.88^{* *}\right)$, pseudostem girth $\left(\mathrm{r}=0.82^{* *}\right)$, number of fingers per hand $\left(\mathrm{r}=0.75^{* *}\right)$, number of functional leaves $(\mathrm{r}=0.74 * *)$, number of hands per bunch $(\mathrm{r}=0.70 * *)$ and pseudostem height $\left(\mathrm{r}=0.64^{* *}\right)$ (T able 2). In the mineral fertilizer + FYM (POP) treatment, the effect of pseudostem height and girth $(351.75 \mathrm{~cm}$ and $51.83 \mathrm{~cm}$ respectively) was significantly pronounced than the other treatments. This might be due to the combined application of $\mathrm{N}$ and $\mathrm{K}$ through high analysis fertilizers in the available form which is also proved from the positive correlation between pseudostem height and girth with foliar $\mathrm{N}\left(\mathrm{r}=0.47^{*}\right.$ and $\left.0.56^{* *}\right)$ and $\mathrm{K}\left(\mathrm{r}=0.53^{*}\right.$ and $0.52 *)$. Ganeshmurthy et al. (2011) have also reported that nitrogen and potassium are the major contributors in dry matter production, yield and quality of banana. The application of lime to correct the $\mathrm{pH}$ of rhizosphere in the POP treatment contributes to nutrient solubilization leading to enhanced plant uptake.

The contribution of compost was also found as effective as POP towards increasing the weight of fingers of banana plants (Table 3). 
Table 2 Correlation between yield, growth and bunch characteristics of banana

\begin{tabular}{|c|c|c|c|c|c|c|c|}
\hline & $\begin{array}{l}\text { Functional } \\
\text { Leaf (No.) }\end{array}$ & $\begin{array}{l}\text { Pseudostem } \\
\text { height }\end{array}$ & $\begin{array}{l}\text { Pseudostem } \\
\text { girth }\end{array}$ & $\begin{array}{l}\text { Bunch } \\
\text { yield }\end{array}$ & No. of hands /Bunch & $\begin{array}{l}\text { Wt. of } \\
\text { fingers }\end{array}$ & $\begin{array}{l}\text { No. of } \\
\text { fingers/hand }\end{array}$ \\
\hline Functional Leaf (No.) & 1 & & & & & & \\
\hline Pseudostem height & 0.407 & 1 & & & & & \\
\hline Pseudostem girth & $.619 * *$ & $.696^{* *}$ & 1 & & & & \\
\hline Bunch yield & $.704 * *$ & $.638 * *$ & $.820 * *$ & 1 & & & \\
\hline No. of hands /Bunch & $.638 * *$ & $.711 * *$ & $.668 * *$ & $.694 * *$ & 1 & & \\
\hline Wt. of fingers & $.816^{* *}$ & $.543 *$ & $.761 * *$ & $.877 * *$ & $.669 * *$ & 1 & \\
\hline No. of fingers/hand & $.746 * *$ & $.622 * *$ & $.613 * *$ & $.751 * *$ & $.603 * *$ & $.728 * *$ & 1 \\
\hline
\end{tabular}

$*(\mathrm{p}<0.05) ; * * \mathrm{p}<0.01$

This may be due to the enhanced microbial activity leading to increased nutrient transformations in the soils receiving compost treatments. Zandonadi et al. (2013) have established that compost treated soils have a capacity to alter the root morphology by gene modification thereby improving its nutrient uptake efficiency. The plants grown under organic nutrition through composting under insitu mode took significantly shorter duration of 206 days for flowering than those grown under recommended dose of fertilizers (264 days). The early maturity was also significantly higher under organic nutrition of plants. The highest benefit: cost ratio of 1.26 was manifested under in-situ composting.

Soils fertilized with mineral fertilizer + FYM (POP), receives a high concentration of nitrogen during the active growth stages which extends the vegetative phase, hence a delayed flowering and harvest. Kranthi (2015) emphasized that the excess nitrogen fuels lead to fast growth of foliage with wider surface so that energy for flower growth is redirected to foliage proliferation leading to

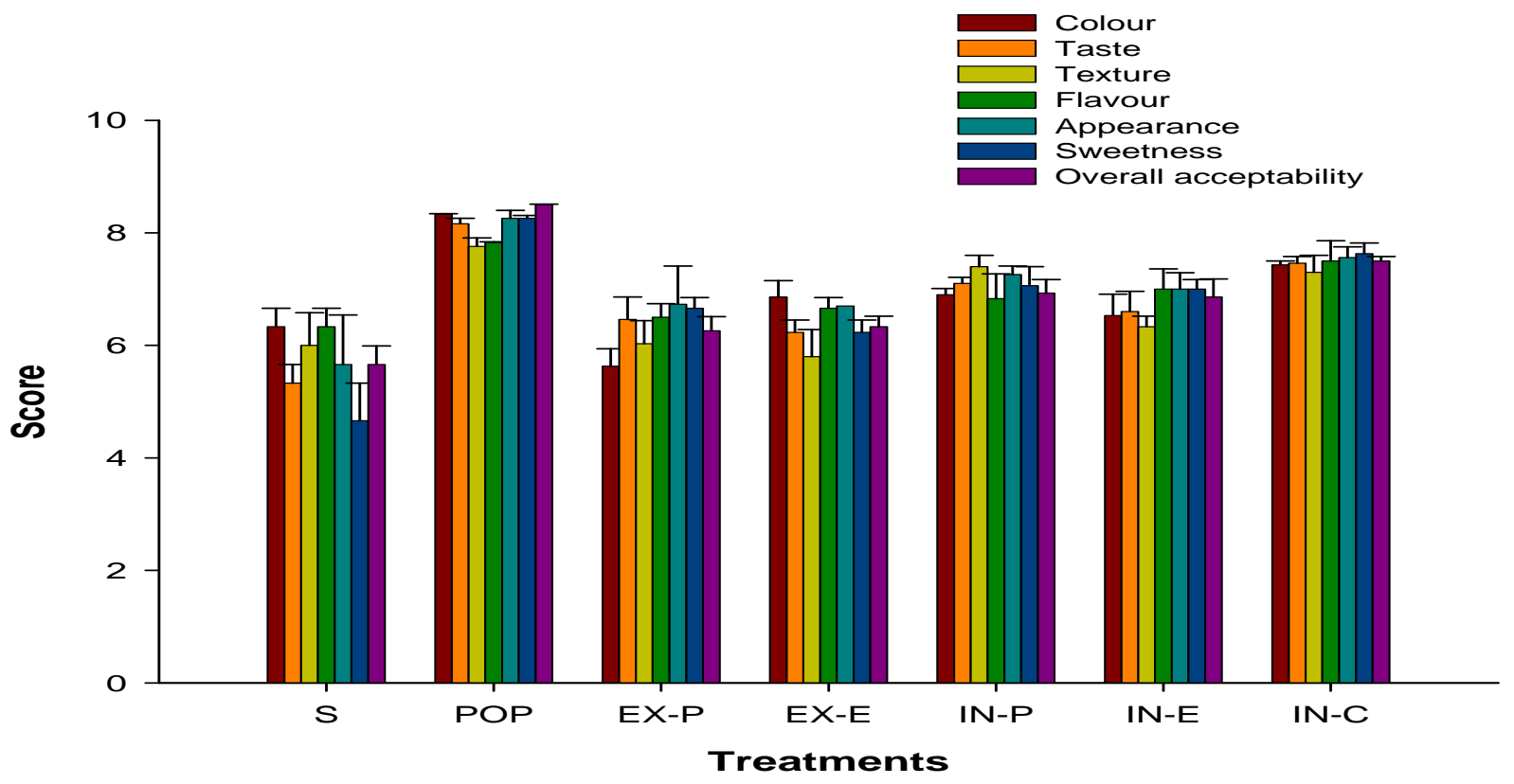

Figure 1 Effect of organic and inorganic nutrition on sensory characteristics of banana fruits

delayed development of necessary reproductive organs. Organic manures on the other hand, prevent an excessive nitrogen influx at any point of time thereby promoting the growth and reproductive phases to take its natural cycles. In-situ vermicomposting could also be more promising due to enrichment of humic substances more acclimatized to that particular environment than those prepared outside the field (Masciandaro et al, 2000)

\subsection{Biochemical quality and sensory parameters of banana $c v$. Nendran}

According to Kramer (1965) quality of foods may be called as the combination of certain characteristics that segregate individual units of a product, and have significance in determining the degree of adequacy of that unit to the consumer. According to Barrett et al. (2010), the characteristics of fruit quality may be defined by four different traits: 1) appearance and colour, 2) taste and aroma i.e. flavour, 3) texture and 4) dietary value. In the present study, the sensory parameters in terms of overall acceptability were more

Journal of Experimental Biology and Agriculture Science http://www.jebas.org 
Table 3 Effect of organic and inorganic nutrition on yield, yield attributes and growth parameters of banana cv. nendran

\begin{tabular}{|c|c|c|c|c|c|c|c|c|c|}
\hline \multirow{2}{*}{ Treatments } & \multirow{2}{*}{$\begin{array}{l}\text { Bunch } \\
\text { yield } \\
\text { (kg/ } \\
\text { plant) }\end{array}$} & \multirow{2}{*}{$\begin{array}{l}\text { Number } \\
\text { of hands } \\
\text { per bunch }\end{array}$} & \multirow{2}{*}{$\begin{array}{l}\text { Number } \\
\text { of fingers } \\
\text { per hand }\end{array}$} & \multirow{2}{*}{$\begin{array}{l}\text { Weight of } \\
\text { one finger } \\
\text { (g) }\end{array}$} & \multicolumn{2}{|c|}{ Pseudostem } & \multicolumn{2}{|c|}{ Time taken (days) for } & \multirow{2}{*}{ Benefit : Cost Ratio } \\
\hline & & & & & $\begin{array}{l}\text { Height } \\
(\mathrm{cm})\end{array}$ & Girth $(\mathrm{cm})$ & Bunching & Harvest & \\
\hline $\mathrm{S}$ & $\begin{array}{c}4.25 \\
(1.12)\end{array}$ & $\begin{array}{c}4.67 \\
(0.33)\end{array}$ & $\begin{array}{c}6.67 \\
(0.88)\end{array}$ & $\begin{array}{l}101.67 \\
(19.13)\end{array}$ & $\begin{array}{l}247.17 \\
(40.65)\end{array}$ & $\begin{array}{l}39.66 \\
(2.59)\end{array}$ & $\begin{array}{c}340 \\
(14.45)\end{array}$ & $\begin{array}{c}431 \\
(36.39)\end{array}$ & - \\
\hline POP & $\begin{array}{l}10.81 \\
(0.49)\end{array}$ & $\begin{array}{c}6.33 \\
(0.14)\end{array}$ & $\begin{array}{c}10.33 \\
(0.43)\end{array}$ & $\begin{array}{c}178.67 \\
(9.91)\end{array}$ & $\begin{array}{c}351.75 \\
(9.27)\end{array}$ & $\begin{array}{l}51.83 \\
(1.24)\end{array}$ & $\begin{array}{c}264 \\
(9.17)\end{array}$ & $\begin{array}{c}345 \\
(10.04)\end{array}$ & 1.11 \\
\hline Ex-P & $\begin{array}{c}7.02 \\
(0.57)\end{array}$ & $\begin{array}{c}6.00 \\
(0.08)\end{array}$ & $\begin{array}{c}8.67 \\
(0.30)\end{array}$ & $\begin{array}{l}147.33 \\
(7.65)\end{array}$ & $\begin{array}{l}295.89 \\
(7.23)\end{array}$ & $\begin{array}{l}45.89 \\
(1.56)\end{array}$ & $\begin{array}{c}248 \\
(2.18)\end{array}$ & $\begin{array}{c}333 \\
(5.79)\end{array}$ & 1.01 \\
\hline Ex-E & $\begin{array}{c}6.73 \\
(0.27)\end{array}$ & $\begin{array}{c}5.33 \\
(0.20)\end{array}$ & $\begin{array}{c}8.33 \\
(0.17)\end{array}$ & $\begin{array}{l}150.67 \\
(8.98)\end{array}$ & $\begin{array}{c}288.39 \\
(5.69)\end{array}$ & $\begin{array}{l}42.42 \\
(0.84)\end{array}$ & $\begin{array}{c}234 \\
(3.83)\end{array}$ & $\begin{array}{c}321 \\
(4.02)\end{array}$ & 1.21 \\
\hline In-P & $\begin{array}{c}6.77 \\
(0.68)\end{array}$ & $\begin{array}{c}5.67 \\
(0.33)\end{array}$ & $\begin{array}{c}9.00 \\
(0.44)\end{array}$ & $\begin{array}{l}155.00 \\
(7.60)\end{array}$ & $\begin{array}{l}298.67 \\
(7.16)\end{array}$ & $\begin{array}{l}44.25 \\
(0.87)\end{array}$ & $\begin{array}{c}221 \\
(6.15)\end{array}$ & $\begin{array}{c}293 \\
(10.12)\end{array}$ & 1.13 \\
\hline In-E & $\begin{array}{c}6.79 \\
(0.27)\end{array}$ & $\begin{array}{c}5.33 \\
(0.25)\end{array}$ & $\begin{array}{c}9.33 \\
(0.33)\end{array}$ & $\begin{array}{l}140.67 \\
(4.68)\end{array}$ & $\begin{array}{l}295.25 \\
(2.24)\end{array}$ & $\begin{array}{l}44.33 \\
(2.09)\end{array}$ & $\begin{array}{c}232 \\
(18.75)\end{array}$ & $\begin{array}{c}310 \\
(13.81)\end{array}$ & 1.17 \\
\hline In-C & $\begin{array}{c}7.24 \\
(0.24)\end{array}$ & $\begin{array}{c}6.00 \\
(0.00)\end{array}$ & $\begin{array}{c}9.00 \\
(1.00)\end{array}$ & $\begin{array}{l}146.33 \\
(2.95)\end{array}$ & $\begin{array}{c}296.08 \\
(3.10)\end{array}$ & $\begin{array}{l}43.83 \\
(1.01)\end{array}$ & $\begin{array}{c}206 \\
(11.41)\end{array}$ & $\begin{array}{c}297 \\
(9.73)\end{array}$ & 1.26 \\
\hline $\mathrm{CD}(\mathrm{p}=0.05)$ & 1.62 & 0.64 & 1.92 & 29.15 & 48.49 & 4.55 & 33.52 & 49.79 & - \\
\hline
\end{tabular}

*Values in parentheses indicate standard error of means; S:Absolute control; POP:300:115:450g N: $\mathrm{P}_{2} \mathrm{O}_{5}: \mathrm{K}_{2} \mathrm{O} / \mathrm{plant}+\mathrm{FYM}(20 \mathrm{~kg} / \mathrm{plant}) ; \mathrm{Ex}-\mathrm{P}$ : ex-situ vermicompost in silpaulin vermibeds with Perionyx excavatus $(20 \mathrm{~kg} / \mathrm{plant})$; Ex-E: ex-situ vermicompost in silpaulin vermibeds with Eisenia foetida (20 kg / plant); In-P: in-situ vermicompost in crop pits with Perionyx excavatus (20 kg / plant); In-E: in-situ vermicompost in crop pits with Eisenia foetida (20 kg / plant) and In-C: in-situ compost in crop pits (20 kg / plant)

Table 4 Effect of organic and inorganic nutrition on chemical and biochemical quality parameters of banana cv. nendran

\begin{tabular}{|c|c|c|c|c|c|c|c|c|c|c|c|c|}
\hline Treatments & $\mathrm{C}$ & $\mathrm{N}$ & $(9)$ & K & $\mathrm{Ca}$ & $\mathrm{Mg}$ & $\begin{array}{c}\text { Vitamin } \\
\text { C } \\
(\mathrm{mg} \\
100 \mathrm{~g}^{-1} \\
\text { of fruit })\end{array}$ & $\begin{array}{l}\text { Titratable } \\
\text { Acidity } \\
\text { ( } \mathrm{g} \text { of citric } \\
\text { acid } 100 \mathrm{~g}^{-1} \\
\text { of fruit) }\end{array}$ & $\begin{array}{l}\text { Shelf } \\
\text { life* } \\
\text { (days) }\end{array}$ & $\begin{array}{l}\text { Total } \\
\text { sugars }\end{array}$ & $\begin{array}{l}\text { Reducing } \\
\text { sugars } \\
(\%)\end{array}$ & $\begin{array}{l}\text { Non- } \\
\text { reducing } \\
\text { sugars }\end{array}$ \\
\hline $\mathrm{S}$ & $\begin{array}{l}33.75 \\
(0.11)\end{array}$ & $\begin{array}{c}2.51 \\
(0.02)\end{array}$ & $\begin{array}{c}0.13 \\
(0.00)\end{array}$ & $\begin{array}{c}0.27 \\
(0.00)\end{array}$ & $\begin{array}{c}0.09 \\
(0.00)\end{array}$ & $\begin{array}{c}0.05 \\
(0.00)\end{array}$ & $\begin{array}{c}9.78 \\
(0.13)\end{array}$ & $\begin{array}{c}0.97 \\
(0.24)\end{array}$ & $\begin{array}{c}10 \\
(1.00)\end{array}$ & $\begin{array}{c}8.30 \\
(0.37)\end{array}$ & $\begin{array}{c}1.65 \\
(0.04)\end{array}$ & $\begin{array}{c}6.66 \\
(0.34)\end{array}$ \\
\hline POP & $\begin{array}{l}39.97 \\
(0.32)\end{array}$ & $\begin{array}{c}2.83 \\
(0.08)\end{array}$ & $\begin{array}{c}0.15 \\
(0.00)\end{array}$ & $\begin{array}{c}0.52 \\
(0.00)\end{array}$ & $\begin{array}{c}0.09 \\
(0.00)\end{array}$ & $\begin{array}{c}0.10 \\
(0.00)\end{array}$ & $\begin{array}{l}20.58 \\
(4.51)\end{array}$ & $\begin{array}{c}0.63 \\
(0.09)\end{array}$ & $\begin{array}{c}20 \\
(2.00)\end{array}$ & $\begin{array}{l}13.35 \\
(0.91)\end{array}$ & $\begin{array}{c}2.72 \\
(0.27)\end{array}$ & $\begin{array}{l}10.63 \\
(0.65)\end{array}$ \\
\hline Ex-P & $\begin{array}{l}35.91 \\
(0.07)\end{array}$ & $\begin{array}{c}3.46 \\
(0.08)\end{array}$ & $\begin{array}{c}0.26 \\
(0.00)\end{array}$ & $\begin{array}{c}0.60 \\
(0.00)\end{array}$ & $\begin{array}{c}0.16 \\
(0.00)\end{array}$ & $\begin{array}{c}0.15 \\
(0.00)\end{array}$ & $\begin{array}{l}17.74 \\
(1.10)\end{array}$ & $\begin{array}{c}0.49 \\
(0.04)\end{array}$ & $\begin{array}{c}18 \\
(2.00)\end{array}$ & $\begin{array}{l}17.82 \\
(0.85)\end{array}$ & $\begin{array}{c}2.55 \\
(0.01)\end{array}$ & $\begin{array}{l}15.27 \\
(0.86)\end{array}$ \\
\hline Ex-E & $\begin{array}{l}38.43 \\
(0.61)\end{array}$ & $\begin{array}{c}2.67 \\
(0.03)\end{array}$ & $\begin{array}{c}0.22 \\
(0.00)\end{array}$ & $\begin{array}{c}0.49 \\
(0.00)\end{array}$ & $\begin{array}{c}0.15 \\
(0.00)\end{array}$ & $\begin{array}{c}0.13 \\
(0.00)\end{array}$ & $\begin{array}{l}17.86 \\
(4.02)\end{array}$ & $\begin{array}{c}0.54 \\
(0.01)\end{array}$ & $\begin{array}{c}14 \\
(2.00)\end{array}$ & $\begin{array}{l}16.42 \\
(0.56)\end{array}$ & $\begin{array}{c}2.55 \\
(0.14)\end{array}$ & $\begin{array}{l}13.87 \\
(0.56)\end{array}$ \\
\hline In-P & $\begin{array}{l}39.59 \\
(0.24)\end{array}$ & $\begin{array}{c}2.59 \\
(0.03)\end{array}$ & $\begin{array}{c}0.22 \\
(0.00)\end{array}$ & $\begin{array}{c}0.51 \\
(0.00)\end{array}$ & $\begin{array}{c}0.08 \\
(0.01)\end{array}$ & $\begin{array}{c}0.12 \\
(0.00)\end{array}$ & $\begin{array}{c}17.93 \\
(0.65)\end{array}$ & $\begin{array}{c}0.50 \\
(0.01)\end{array}$ & $\begin{array}{c}18 \\
(2.00)\end{array}$ & $\begin{array}{l}20.96 \\
(1.01)\end{array}$ & $\begin{array}{c}3.71 \\
(0.24)\end{array}$ & $\begin{array}{l}17.25 \\
(0.87)\end{array}$ \\
\hline In-E & $\begin{array}{l}36.65 \\
(0.28)\end{array}$ & $\begin{array}{c}2.38 \\
(0.03)\end{array}$ & $\begin{array}{c}0.20 \\
(0.00)\end{array}$ & $\begin{array}{c}0.43 \\
(0.00)\end{array}$ & $\begin{array}{c}0.07 \\
(0.00)\end{array}$ & $\begin{array}{c}0.11 \\
(0.00)\end{array}$ & $\begin{array}{l}17.12 \\
(0.98)\end{array}$ & $\begin{array}{c}0.29 \\
(0.06)\end{array}$ & $\begin{array}{c}13 \\
(1.00)\end{array}$ & $\begin{array}{l}22.41 \\
(1.58)\end{array}$ & $\begin{array}{c}3.61 \\
(0.50)\end{array}$ & $\begin{array}{l}18.80 \\
(1.10)\end{array}$ \\
\hline In-C & $\begin{array}{l}36.35 \\
(0.30)\end{array}$ & $\begin{array}{c}2.56 \\
(0.09)\end{array}$ & $\begin{array}{c}0.25 \\
(0.00)\end{array}$ & $\begin{array}{c}0.59 \\
(0.00)\end{array}$ & $\begin{array}{c}0.12 \\
(0.00)\end{array}$ & $\begin{array}{c}0.14 \\
(0.00)\end{array}$ & $\begin{array}{l}19.03 \\
(1.87)\end{array}$ & $\begin{array}{c}0.43 \\
(0.01)\end{array}$ & $\begin{array}{c}15 \\
(1.00)\end{array}$ & $\begin{array}{l}22.27 \\
(1.77)\end{array}$ & $\begin{array}{c}3.54 \\
(0.10)\end{array}$ & $\begin{array}{l}18.74 \\
(1.69)\end{array}$ \\
\hline $\mathrm{CD}$ (at 5\%) & 1.02 & 0.18 & 0.01 & 0.01 & 0.02 & 0.01 & 2.92 & 0.29 & 4.98 & 3.55 & 0.79 & 3.06 \\
\hline *Values in $p$ & heses & licate & dard & $\mathrm{r}$ of $\mathrm{n}$ & & & & & & & & \\
\hline
\end{tabular}

significant in mineral fertilizer + FYM treated plants (score of 8.5) (Figure 1). However, both mineral and organic modes of nut rition had a more or less similar influence on the vitamin $\mathrm{C}$ content as evidenced in Table 4 , the vitamin $\mathrm{C}$ content of $20.58 \mathrm{mg} / 100 \mathrm{~g}$ of fruit in POP and $19.03 \mathrm{mg} / 100 \mathrm{~g}$ of fruit in IN-C and shelf life of 20days for POP as against 19.03 days in EX-P. The titratable acidity was more pronounced under inorganic mode of nutrition whereas the sugar content of the fruits was superior under in-situ 
composting mode. The return of residues to soil as compost enriches the site with more biological activity, increased growth and plant performances and ultimately enhances yield and quality of crops (Pathma \& Sakthivel, 2012).

The highest content of total sugars was recorded in plants grown under vermicompost prepared in banana planting pits using $E$. foetida which was at par with the in-situ compost. In-situ composting process always favoured formation of humic acids rich in polysaccharides, which might have resulted in the translocation of assimilates. Among the treatments, the fruits from mineral fertilizer + FYM treated plants were significantly superior in all the parameters.

The highest content of $\mathrm{C}$ was from fruits of plants which received mineral fertilizer + FYM and that received in-situ vermicompost prepared by native earthworms. The increased translocation of photosynthates to the sink under conjunctive application of inorganic fertilizers + FYM and vermicompost was proved from this study. This is further confirmed by the higher number of functional leaves and weight of finger obtained from those plants receiving recommended dose of fertilizers and FYM and vermicompost.
The content of $\mathrm{P}, \mathrm{K}, \mathrm{Ca}$ and $\mathrm{Mg}$ was significantly higher in fruits of plants that received native earthworm worked ex-situ vermicompost prepared in silpaulin vermibeds. However the P, K, $\mathrm{Ca}$ and $\mathrm{Mg}$ content of fruits were significantly higher in the in-situ compost treated plots. The presence of earthworm derived humic substances in the rhizosphere soils might have stimulated the proliferation of lateral roots and thereby increased the uptake and translocation of nutrients to fruits (Trevisan et al., 2010). The slow release coupled with constant uptake of nutrients would have a stimulatory effect on the content of nutrients in the fruits receiving organic nutrition through vermicomposting. Zandonadi et al. (2013) reported that humic substances have direct influence on the root morphology and nutrient uptake. Undeniably, composts and vermicomposts from agricultural wastes have proved to be influential sources of natural organic fertilizers (Busato et al., 2012) with biological properties directly affecting the physiological functioning of plants and thereby structural modification unlike that of mineral fertilizers (Zandonadi \& Busato, 2012). Significantly higher Ca content in fruits was recorded from plants treated with exotic earthworm (E. foetida) worked vermicompost.

Table 5 Effect of organic and inorganic nutrition on chemical properties of rhizosphere soils $(0-30 \mathrm{~cm}$ depth $)$ after the harvest of banana

\begin{tabular}{|c|c|c|c|c|c|c|c|c|}
\hline \multirow[b]{2}{*}{ Treatments } & \multirow[b]{2}{*}{$\mathrm{pH}$} & \multirow{2}{*}{$\begin{array}{c}\mathrm{EC} \\
\mathrm{dSm}^{-1}\end{array}$} & \multirow{2}{*}{$\begin{array}{c}\text { Walkley } \\
\text { Black } \\
\text { Carbon } \\
(\%)\end{array}$} & Av. N & Av. P & \multirow[t]{2}{*}{ Av. K } & \multicolumn{2}{|c|}{ Av. $\mathrm{Mg}$} \\
\hline & & & & & (kg/ha) & & \multicolumn{2}{|c|}{$\mathrm{mg} \mathrm{kg}^{-1}$ of soil } \\
\hline \multirow{2}{*}{$\mathrm{S}$} & 4.50 & 0.01 & 0.59 & 232.88 & 35.47 & 229.84 & 307.41 & 90.07 \\
\hline & $(0.15)$ & $(0.00)$ & $(0.07)$ & (3.19) & $(1.17)$ & $(26.88)$ & $(4.60)$ & $(0.70)$ \\
\hline \multirow{2}{*}{ POP } & 5.30 & 0.04 & 0.76 & 295.64 & 72.95 & 638.38 & 656.47 & 90.94 \\
\hline & $(0.13)$ & $(0.00)$ & $(0.14)$ & $(5.45)$ & $(1.23)$ & (92.27) & (4.88) & (1.85) \\
\hline \multirow{2}{*}{ Ex-P } & 5.3 & 0.03 & 1.18 & 267.99 & 62.85 & 510.44 & 417.31 & 93.93 \\
\hline & $(0.04)$ & $(0.00)$ & $(0.11)$ & $(5.01)$ & (1.08) & $(65.83)$ & (19.49) & $(1.58)$ \\
\hline \multirow{2}{*}{ Ex-E } & 5.9 & 0.05 & 0.98 & 291.22 & 63.93 & 370.98 & 371.25 & 90.31 \\
\hline & $(0.09)$ & $(0.00)$ & $(0.15)$ & (12.33) & $(1.05)$ & (17.66) & (10.98) & $(1.54)$ \\
\hline \multirow{2}{*}{ In-P } & 5.6 & 0.02 & 1.04 & 280.86 & 47.08 & 579.63 & 540.07 & 91.59 \\
\hline & $(0.04)$ & $(0.00)$ & $(0.04)$ & (1.91) & (1.91) & $(5.17)$ & (16.96) & $(0.65)$ \\
\hline \multirow{2}{*}{ In-E } & 4.8 & 0.02 & 0.78 & 312.58 & 50.89 & 410.68 & 449.64 & 92.65 \\
\hline & $(0.10)$ & $(0.00)$ & (0.09) & $(3.63)$ & $(2.31)$ & $(75.06)$ & $(21.91)$ & $(0.61)$ \\
\hline \multirow{2}{*}{ In-C } & 5.8 & 0.02 & 1.26 & 310.00 & 33.60 & 447.21 & 587.12 & 103.27 \\
\hline & $(0.06)$ & $(0.00)$ & $(0.11)$ & (15.12) & $(0.76)$ & $(20.66)$ & $(7.82)$ & $(0.51)$ \\
\hline $\mathrm{CD}(\mathrm{p}=0.05)$ & 0.4 & 0.001 & 0.11 & 26.64 & 4.56 & 166.27 & 46.02 & 3.74 \\
\hline
\end{tabular}

S:Absolute control; POP:300:115:450g N:P2O5:K2O/plant + FYM (20 kg/plant); Ex-P: ex-situ vermicompost in silpaulin vermibeds with S:Absolute control; POP:300:115:450g N:P2O5:K2O/plant + FYM (20 kg/plant); Ex-P: ex-situ vermicompost in silpaulin vermibeds with Perionyx excavatus (20 kg/plant); Ex-E: ex-situ vermicompost in silpaulin vermibeds with Eisenia foetida *Values in parentheses indicate standard error of means; (20 kg / plant); In-P: in-situ vermicompost in crop pits with Perionyx excavatus (20 kg / plant); In-E: in-situ vermicompost in crop pits with Eisenia foetida $(20 \mathrm{~kg} /$ plant $)$ and In-C: in-situ compost in crop pits (20 kg / plant) 
Table 6 Effect of organic and inorganic nutrition on biochemical properties of rhizosphere soils $(0-30 \mathrm{~cm}$ depth) after the harvest of banana

\begin{tabular}{|c|c|c|c|c|c|c|c|c|}
\hline \multirow{2}{*}{ Treatments } & $\begin{array}{c}\text { Microbial } \\
\text { biomass } \\
\text { carbon }\end{array}$ & $\begin{array}{c}\text { Auxin } \\
\text { equivalents }\end{array}$ & $\begin{array}{c}\text { Total } \\
\text { microbial } \\
\text { count }\end{array}$ & $\begin{array}{l}\text { Urease } \\
\text { activity }\end{array}$ & $\begin{array}{c}\text { Asparaginase } \\
\text { activity }\end{array}$ & $\begin{array}{c}\text { Dehydrogenase } \\
\text { activity }\end{array}$ & $\begin{array}{l}\text { Alkaline } \\
\text { phosphatase }\end{array}$ & $\begin{array}{c}\text { Acid } \\
\text { phosphat ase }\end{array}$ \\
\hline & \multicolumn{2}{|c|}{$\mu \mathrm{g} \mathrm{g}^{-1}$ of soil } & $\begin{array}{l}10^{5} \mathrm{CFU} \\
\mathrm{g}^{-1} \text { of soil }\end{array}$ & \multicolumn{2}{|c|}{$\mathrm{mg} \mathrm{kg}^{-1}$ of soil } & $\left(\begin{array}{c}\mu \mathrm{g} \text { TPF day } \\
\left.{ }^{-1}\right) \\
\mathrm{kg}\end{array}\right.$ & \multicolumn{2}{|c|}{$\left(\mu \mathrm{g}\right.$ PNP $\left.g^{-1} h^{-1}\right)$} \\
\hline S & $\begin{array}{l}80.94 \\
(0.82)\end{array}$ & $\begin{array}{l}50.80 \\
(1.31)\end{array}$ & $\begin{array}{l}30.03 \\
(2.14)\end{array}$ & $\begin{array}{l}62.66 \\
(3.94)\end{array}$ & $\begin{array}{l}101.61 \\
(1.14)\end{array}$ & $\begin{array}{l}72.87 \\
(2.57)\end{array}$ & $\begin{array}{l}25.01 \\
(0.37)\end{array}$ & $\begin{array}{l}21.86 \\
(0.19)\end{array}$ \\
\hline POP & $\begin{array}{l}117.51 \\
(1.41)\end{array}$ & $\begin{array}{l}128.72 \\
(2.16)\end{array}$ & $\begin{array}{l}62.04 \\
(11.05)\end{array}$ & $\begin{array}{l}87.91 \\
(3.23)\end{array}$ & $\begin{array}{l}163.31 \\
(7.52)\end{array}$ & $\begin{array}{l}178.81 \\
(4.02)\end{array}$ & $\begin{array}{l}356.18 \\
(1.35)\end{array}$ & $\begin{array}{l}622.35 \\
(2.69)\end{array}$ \\
\hline Ex-P & $\begin{array}{l}144.68 \\
(5.36)\end{array}$ & $\begin{array}{l}117.86 \\
(13.20)\end{array}$ & $\begin{array}{l}109.01 \\
(9.79)\end{array}$ & $\begin{array}{l}70.90 \\
(1.41)\end{array}$ & $\begin{array}{l}154.02 \\
(4.05)\end{array}$ & $\begin{array}{l}143.56 \\
(3.10)\end{array}$ & $\begin{array}{l}82.48 \\
(7.98)\end{array}$ & $\begin{array}{l}120.66 \\
(5.68)\end{array}$ \\
\hline Ex-E & $\begin{array}{c}268.16 \\
(1.11)\end{array}$ & $\begin{array}{l}61.21 \\
(0.62)\end{array}$ & $\begin{array}{l}21.32 \\
(1.39)\end{array}$ & $\begin{array}{l}87.79 \\
(4.03)\end{array}$ & $\begin{array}{l}149.65 \\
(6.09)\end{array}$ & $\begin{array}{c}74.36 \\
(10.74)\end{array}$ & $\begin{array}{l}183.33 \\
(4.29)\end{array}$ & $\begin{array}{l}27.40 \\
(0.74)\end{array}$ \\
\hline In-P & $\begin{array}{c}280.72 \\
(2.64)\end{array}$ & $\begin{array}{l}61.43 \\
(0.66)\end{array}$ & $\begin{array}{l}44.01 \\
(7.39)\end{array}$ & $\begin{array}{l}101.29 \\
(4.61)\end{array}$ & $\begin{array}{l}163.68 \\
(5.59)\end{array}$ & $\begin{array}{l}88.07 \\
(1.46)\end{array}$ & $\begin{array}{l}35.96 \\
(0.79)\end{array}$ & $\begin{array}{c}337.30 \\
(4.96)\end{array}$ \\
\hline In-E & $\begin{array}{l}504.61 \\
(14.44)\end{array}$ & $\begin{array}{l}65.82 \\
(3.74)\end{array}$ & $\begin{array}{l}69.16 \\
(5.48)\end{array}$ & $\begin{array}{l}100.06 \\
(1.71)\end{array}$ & $\begin{array}{l}203.42 \\
(5.71)\end{array}$ & $\begin{array}{l}113.43 \\
(2.78)\end{array}$ & $\begin{array}{l}28.10 \\
(2.21)\end{array}$ & $\begin{array}{l}64.09 \\
(3.79)\end{array}$ \\
\hline In-C & $\begin{array}{l}427.92 \\
(3.28)\end{array}$ & $\begin{array}{l}144.14 \\
(2.36)\end{array}$ & $\begin{array}{l}89.31 \\
(4.24) \\
\end{array}$ & $\begin{array}{l}141.81 \\
(2.44) \\
\end{array}$ & $\begin{array}{l}168.29 \\
(11.65) \\
\end{array}$ & $\begin{array}{l}223.78 \\
(7.03) \\
\end{array}$ & $\begin{array}{l}60.46 \\
(3.32) \\
\end{array}$ & $\begin{array}{l}267.20 \\
(7.57) \\
\end{array}$ \\
\hline $\mathrm{CD}$ at $5 \%$ & 17.94 & 16.73 & 9.29 & 8.75 & 16.13 & 14.52 & 11.75 & 12.35 \\
\hline
\end{tabular}

*Values in parentheses indicate st andard error of means; S:A bsolute control; POP:300:115:450g N:P ${ }_{2} \mathrm{O}_{5}: \mathrm{K}_{2} \mathrm{O} / \mathrm{plant}+\mathrm{FYM}(20 \mathrm{~kg} / \mathrm{plant})$; Ex-P: ex-situ vermicompost in silpaulin vermibeds with Perionyx excavatus $(20 \mathrm{~kg} / \mathrm{plant})$; Ex-E: ex-situ vermicompost in silpaulin vermibeds with Eisenia foetida (20 kg/ plant); In-P: in-situ vermicompost in crop pits with Perionyx excavatus (20 kg / plant); In-E: in-situ vermicompost in crop pits with Eisenia foetida (20 kg / plant) and In-C: in-situ compost in crop pits (20 kg/plant)

The study shows that combined use of fertilizers and FYM had significant influence on the available nutrient status of the rhizosphere soil particularly the level of N, P, K and Ca (Table 5). Since the availability of $\mathrm{P}$ is in plenty, the activity of phosphatase enzyme was significantly higher under mineral fertilizer + FYM treatment. The high concentration of auxins from rhizosphere of banana grown under mineral fertilizer + FYM may be due to the root exudation and microbial production. Different modes of organic nutrition also have significant influence on soil fertility. For example, the ex-situ mode of composting using native earthworm P. excavatus improved the soil with more content of Walkley Black Carbon, available $\mathrm{K}$ and microbial count, whereas soil factors such as $\mathrm{pH}$ and available $\mathrm{N}$ content of soil were higher under ex-situ vermicomposting using exotic worms $E$. foetida.

Under in-situ vermicomposting, native earthworms had significant influence on available $\mathrm{K}$ content of the soil, whereas available $\mathrm{N}$, microbial biomass, carbon and asparaginase activity was significantly pronounced under E. foetida produced wormicasts. Further, in-situ composting also had significant influence on rhizosphere $\mathrm{pH}$, Walkley Black Carbon, available nutrients like $\mathrm{N}$ and $\mathrm{Mg}$, auxin content, urease and dehydrogenases activities of soil (Table 6). In general, the integrated management practices (mineral fertilizers + FYM) resulted in better yields of banana, but the benefit: cost ratio was more for the crops grown under organic nutrition. The higher benefit: cost ratio under organic banana nutrition can be attributed primarily to the less cost involved in the farming practices compared to mineral fertilizer + FYM treatment and also to premium price for the organic fruits in the market.

\section{Conclusion}

The soil ameliorant properties of compost was proved by their $\mathrm{pH}$ and calcium content. Besides soil reaction, composts could also effectively manage the chemical and biochemical properties of soil. The quality parameters of banana fruits as well as the soil health were remarkably improved under in-situ composting besides assuring the economic viability. Though the integrated management practices (mineral fertilizers + FYM) resulted in better yields of banana, but maximum benefit: cost ratio was reported form the crops grown under organic nutrition. Thus organic nutrition using in-situ composting could be considered a promising technology for in-situ waste management and organic nutrient recycling.

\section{References}

Allison SD, Wallenstein MD, Bradford MA (2010) Soil carbon response to warming dependent on microbial physiology. Nature Geoscience 3:336-340. doi:10.1038/ngeo846.

Aremu AO, Kulkarni MG, Bairu MW, Finnie JF, Staden JV (2012) Growth stimulation effects of smoke-water and vermicompost leachate on greenhouse grown-tissue-cultured 'Williams' bananas. Plant Growth Regulators 66:111-118.

Association of Official Analytical Chemists (2000) Official and tentative methods of analysis, Washington, D.C., US. Pp. 757.

Athani SI, Hulamani NC (2000) Effect of Vermicompost on Fruit Yield and Quality of Banana cv. Rajapuri (Musa AAB) Journal of Farm Sciences 13 : 942-946. 
Balamohan TN, Kavitha PS (2005) An overview of Production Constraints and Management in Tropical Fruit Crops. In: Balamohan TN, Vijayakumar RM, Soorianathasundaram K, Poornima K, Vadivel E (Eds.), Management of Production Problems in Tropical Fruit Crops, Tamil Nadu Agricultural University, Coimbatore. Pp. 182

Barrett DM, Beaulieu JC, She wfelt R (2010) Color, favor, texture, and nutritional quality of fresh-cut fruits and vegetables: desirable levels, instrumental and sensory measurement, and the effects of processing. Critical Reviews in Food Science and Nutrition 50:369-389.

Busato JG, Lima L, Aguiar NO, Canellas LP, Olivares FL (2012) Changes in labile phosphorus forms during maturation of vermicompost enriched with phosphorus-solubilizing and diazotrophic bacteria. Bioresource Technology 110:390-395.

Canellas LP, Olivares FL (2014) Physiological responses to humic substances as plant growth promoter. Chemical and Biological Technologies in Agriculture1 : 1-11.

Dakora FD Phillips DA (2002) Root exudates as mediators of mineral acquisition in low-nutrient environments. Plant and Soil 245:35-47.

Das MN, Giri NC (1986) Design and Analysis of Experiments, $\left(2^{\text {nd }}\right.$ Ed.), New Age International (P) Limited Publishers, New Delhi. 364p.

Ganeshamurthy AN, Satisha GC, Patil P (2011) Potassium nutrition on yield and quality of fruit crops with special emphasis on banana and grapes. Karnataka Journal of Agricultural Sciences 24: $29-38$

Government of India (1985) The Fertilizer (Control) Order, Department of Agriculture and Cooperation, Ministry of Agriculture and Rural Development, New Delhi. Pp. 91.

Government of Kerala (2016) Agricultural Statistics 2014-15, Department of Economics and Statistics, Thiruvanathapuram, Kerala, Pp.130.

Indian Agricultural Research Institute (2012) Crop residues management with conservation agriculture: Potential, constraints and policy needs. Indian Agricultural Research Institute, New Delhi, Pp. 32.

Ingale S, Joshil SJ, Gupte A (2014) Production of bioethanol using agricultural waste: Banana pseudo stem. Brazilian Journal of Microbiology $45: 885-892$.

Jackson ML (1958) Soil chemical analysis. Prentice Hall Inc., Englewood Cliffs, New Jersey, Pp. 110.

Juárez PDA, de la Fuente JL Paulín RV (2011) Vermicomposting as a process to stabilize organic waste and sewage sludge as an application for soil. Tropical and Subtropical Agroecosystems 14: 949-963.
Kerala Agricultural University (2011) Package of Practices Recommendations: Crops. $\left(14^{\text {th }}\right.$ Ed). Kerala Agricultural University, Thrissur, Pp. 360.

Kramer A (1965) Evaluation of quality of fruits and vegetables In: Irving Jr. GW, Hoover SR (Eds.), Food Quality American Association for the Advancement of Science, Washington, DC, pp. 9-18.

Kranthi KR (2015) The three mistakes in cotton's life. In: Singh A (Ed.), Cotton Statistics and News, Cotton Association of India, Nagpur, India [on-line]. Available: http://www.cicr.org.in/pdf/Kranthi_art/3-Mistakes.pdf accessed on 06 October 2015.

Lee KE (1992) Some trends opportunities in earthworm research or: Darwin's children. The future of our discipline. Soil Biology and Biochemistry 24:1765-1771. DOI: http://dx.doi.org/10.1016/0038-0717 (92)90185-Z

Luo YQ, Wan SQ, Hui DF, Wallace LL (2001) Acclimatization of soil respiration to warming in a tall grass prairie. Nature 413: 622625. DOI: $10.1038 / 35098065$

Masciandaro G, Ceccanti B, Garcia C (2000) "In situ" vermicomposting of biological sludges and impacts on soil quality. Soil Biology and Biochemistry 32: 1015-1024. DOI: 10.1016/S0038-0717(00)00011-0

National Horticultural Board (2015) Annual report 2014 - 15. Ministry of Agriculture \& Farmers Welfare, Govt. of India, Pp.124.

National Horticulture Mission (2005) Annual plan of action under National Horticulture Mission 2005 [on-line]. Available on: http://nhm.nic.in/ActionPlan/ActionPlan_Kerala.pdf accessed on 18 November 2005.

Padmavathiamma PK, Li LY, Kumari UR (2008) An experimental study of vermibiowaste composting for agricultural soil improvement. Bioresource Technology 99: 1672-1681. DOI: 10.1016/j.biortech.2007.04.028

Parthasarathi K (2010) Earthworms - life cycle, compost and therapy. Lap Lambert Academic Publishing AG \& Co, Germany.

Parthasarathi K, Balamurugan M, Prashija KV, Jayanthi L, Basha SA (2016) Potential of Perionyx excavatus (Perrier) in lignocellulosic solid waste management and quality vermifertilizer production for soil health. International Journal of Recycling of Organic Wastes in Agriculture 5:65-86.

Parthasarathi K, Ranganathan LS, Anandi V, Zeyer J (2007) Diversity of microflora in the gut and casts of tropical composting earthworms reared on different substrates. Journal of Environmental Biology 28:87-97. 
Pathma J, Sakthivel N (2012) Microbial diversity of vermicompost bacteria that exhibit useful agricultural trait and waste management potential. Springer Plus 1:26.

Pattnaik S, Reddy MV (2010) Nutrient status of vermicompost of urban green waste processed by three earthworm species-Eisenia fetida, Eudrilus eugeniae, and Perionyx excavatus. Applied and Environmental Soil Science $\quad$ Pp. http://dx.doi.org/10.1155/2010/967526

Pepper IL, Gerba CP, Brendecke J W (2004) Environmental Microbiology: A laboratory manual, $\left(2^{\text {nd }} E d\right)$. Academic Press Inc. New York, USA. pp71-76.

Sarma UJ, Chakravarty M, Bhattacharya HC (2012) Production of in-situ vermicompost as affected by earthworm's inoculation, season and farm wastes. Indian Journal of Agricultural Research $46: 234-241$.

Schnitzer M (1982) Organic matter characterization. In: Page AL, Miller RH, Keeney DR (Eds.), Methods of Soil Analysis Part 2, Chemical and Microbiological Properties'. Agronomy No. 9. ( $2^{\text {nd }}$ Ed.). Madison, Wisconsin, USA. pp. 581-594.

Smith RO (2012) Sanjeevak as a source of nutrients and phytohormones for production and propagation of plants. Dissertation presented for the degree of Doctor of Philosophy in Agricultural Sciences at the University of Stellenbosch, Pp 160.

Subbiah BV, A sija GL (1956) A rapid procedure for estimation of available nitrogen in soils. Current Science 25: 259-260.

Suthar S (2009) Growth and fecundity of earthworms: Perionyx excavatus and Perionyx sansibaricus in cattle waste solids. Environment alist 29.78-84. DOI:10.1007/110669-008-9185-1

Trevisan S, Francioso O, Quaggiotti S, Nardi S (2010) Humic substances biological activity at the plant-soil interface - From environmental aspects to molecular factors. Plant Signaling \& Behavior 5 : 635-643. http://dx.doi.org/10.4161/psb.5.6.11211

Vinotha SP, Parthasarathi K, Ranganathan LS (2000) Enhanced phosphatase activity in earthworm casts is more of microbial origin. Current Science 79:1158-1159.

Walkley A, Black IA (1934) An examination of the Degtareff method for determining soil organic matter and a proposed modification of the chromic acid titration method. Soil Science 37: 29-38. DOI: http://dx.doi.org/10.1097/00010694-19340100000003 .

Wohler I (1997) Auxin-indole derivatives in soils determined by a colorimetric method and by high performance liquid chromatography. Microbiological Research152:399-405.

Wollum AG (1982) Methods of Soil Analysis. Madison, Wisconsin, USA, Pp.781-801.

Zandonadi DB, Busato JG (2012) Vermicompost humic substances: technology for converting pollution into plant growth regulators. International Journal of Environmental Science and Engineering Technology 3:73-84.

Zandonadi DB, Santos MP, Busato JG, Peres LEP, Facanha AR (2013) Plant physiology as affected by humified organic matter. Theoretical and Experimental Plant Physiology 25: 12-25 DOI: $10.1590 / \mathrm{S} 2197-00252013000100003$ 